\title{
Academic Fraud among Students in Higher Education in Nigeria: Reasons, Methods Adopted and Strategies to curb it
}

\author{
Ezinwa B. Azuka Ph.D \\ Department of Office Technology and Management \\ Federal Polytechnic, Oko, Anambra State, Nigeria
}

\section{Doi:10.5901/jesr.2014.v4n3p289}

\begin{abstract}
Academic fraud can encompass any crime for gain that uses deception as its principal modus operandi" (Wells, 2005) The purpose of this study is to expose to stakeholders in the education sector in Nigeria of the volume of academic fraud (cheating) that is taking place in the educational institutions especially in the tertiary level and to expose some of the strategies employed by perpetrators of this heinous crime and to proffer measures that can be employed to reduce the likelihood of its occurrence. In order to address these issues, four research questions were advanced which include: What are the causes of academic fraud among students in the Nigerian education sector? What are the various types of academic fraud prevalent in tertiary institutions in Nigeria? What are the methods adopted in committing these frauds by both students and teachers. What are the strategies needed to reduce the occurrence of these frauds in educational institutions. This study has identified 14 causes of academic fraud, 22 methods of committing academic fraud, and 24 techniques for combating academic fraud.
\end{abstract}

Keywords: Academic, fraud, education, strategies, institutions

\section{Introduction/Theoretical Framework}

It has become a subject of general discourse that the standard of education has fallen and one of the parameters to support this assertion is the spate of academic fraud prevalent in our educational institutions. Romney \& Steinbart $(2003$,$) define fraud as any means to gain an unfair advantage and include: lying, suppression of the truth, tricks, cunning$ and violation of trust. Donald R. Cressey quoted in Wells (2005) identified a tripartite structure for examining student cheating and developing prevention and detection techniques. These according to him make up what is called the fraud triangle. For him, fraud could be triggered off by perceived pressure, rationalization and perceived opportunity. According to Whitley \& Keith-Spiegel (2002), student pressure falls into six broad categories: 1) performance concerns (e.g. failing a course, grade pressure), 2) external pressures (e.g. academic pressures, such as work load or number of tests on one day, or nonacademic pressures, such as parental expectations, GPA required for financial aid, etc.), 3) unfair professors, 4) lack of effort (not putting in enough effort to succeed so pressure is increased), 5) other loyalties such as helping a friend or helping a member of a fraternity or sorority, 6 ) other items (such as viewing cheating as a game or a challenge).

Rationalization the second piece in the fraud triangle allows a student to justify cheating by creating a reason for cheating that is more compelling than honesty or integrity. Common student justifications include: cheating hurts no one; no one ever gets caught; friends come first or he/she needed my help; I only cheat in classes that aren't important to my major; everyone does it; I could lose my scholarship (or my parents will kill me) if I don't do well (Pillsbury, 2004; Whitley; Keith-Spiegel, 2002). Rationalization includes a belief on the part of the cheater that what they are doing is not actually unethical. This is especially true when technology is used to cheat or defraud. A student might find shoplifting software from a computer store reprehensible, but will illegally copy a software program from a friend. Most students would not break into a physical office, but see hacking into a computer system as a challenge rather than an ethical breach. Digital materials can be duplicated easily; a student might argue that it is not "stealing" if the article taken without attribution leaves the original in place and undamaged.

Perceived opportunity is the third piece of the fraud triangle and lends itself to internal controls and faculty intervention more readily than the other two elements. A student perceives an opportunity to cheat when he or she identifies a method to cheat. There are literally hundreds of ways students can cheat and there are numerous references available for those individuals looking for ideas on how to cheat.

It should be said that the ways to cheat are limited only by students' imaginations, and that cheating methods continually increase in sophistication. One of the biggest boons to cheating has been improved technology that is readily 
available for lower and lower prices. Cizek (1999) suggests grouping cheating methodologies into three broad categories: 1) giving, taking or receiving information from other person(s), 2) using prohibited materials to complete an assignment, and 3) capitalizing on a weakness to gain an advantage.

\section{Statement of the Problem}

Academic dishonesty is endemic at all levels of education and Academic fraud is reaching epidemic proportions worldwide (Desruisseaux, 1999). Academic fraud has become a business in some countries and individuals and groups engage in malpractice for monetary gain. According to the International Institute for Educational Planning (IIEP) academic fraud seems to be on the increase across the world. The existing literature looks primarily at the role of students in committing fraud. Studies in the United States show that $20 \%$ of students started cheating in the first grade. Similarly, other studies in the U.S further reveal that $56 \%$ of middle school students and $70 \%$ of high school students have cheated. Students are not the only ones to cheat in an academic setting. A study among North Carolina school teachers found that some 35 percent of respondents said they had witnessed their colleagues cheating in one form or another. The rise of high-stakes testing and the consequences of the results on the teacher are cited as a reason why a teacher might want to inflate the results of their students.

Cheating has permeated various professional sports (use of banned drugs to enhance performance in sports). FIFA had to suspend three of its senior committee members and barred them from voting in 2010 to select the venue of the 2018 World Cup. Bell (2005) in another study found that $75 \%$ to $80 \%$ of all college students cheat on at least one assignment or test. Cheating such as over bloated financial statements by banks to deceive the investing public has become the order of the day in business. Cheating in schools to get admitted into college or to gain unmerited marks is escalating (Wall Street, 2005). This cheating behavior is critical to nip in the bud as the literature suggests that students who are academically dishonest often transfer this undesirable behavior to the corporate environment after graduation (Chapman et al., 2004).

Plagiarism, another form of academic fraud is the use or close imitation of the language and thoughts of another author and the representation of them as one's own original work. Within academia, plagiarism by students, professors, or researchers is considered academic dishonesty or academic fraud and offenders are subject to academic censure. Some individuals caught plagiarizing in academic or journalistic contexts claim that they plagiarized unintentionally, by failing to include quotations or give the appropriate citation. While plagiarism in scholarship and journalism has a centuries-old history, the development of the Internet, where articles appear as electronic text, has made the physical act of copying the work of others much easier, simply by copying and pasting text from one web page to another. A critical look at the issues identified here raises a number of question marks on the credibility of the certificates obtained from Nigerian tertiary institutions. It is therefore the objective of this study to identify the causes and types of academic frauds experienced in our tertiary institutions with a view to proffering suggestions, strategies and techniques to combat this hydra-headed social vice.

\section{Methods}

\subsection{Design consideration}

In a Cochrane review, Shaw, Cheater, Baker, Gillies, Flottorp, and Robertson (2005) found interviews and surveys among professionals or focus groups as effective approaches for measuring opinions. In this study a cross-sectional survey design was used. The survey was carried out in 2009. From literature review, the author was able to derive a questionnaire called Academic Fraud, Causes, Methods and Prevention Questionnaire (AFCMPQ) comprising of 51 items. The reliability was tested using Cronbach's alpha statistics, and the measures were sufficiently consistent (Polit and Hungler, 1999).

\subsection{Population of the study}

Nigeria as a country consists of 6 geopolitical zones. In each of these zones, two tertiary institutions (one university and one polytechnic) were selected for this study. Thus, from six geopolitical zones, 12 tertiary institutions were used for the study. 989 respondents, comprising726 students and 263 lecturers in these tertiary institutions participated in the study. In all 860 copies of the questionnaire were duly completed and returned giving a percentage return of $69.4 \%$. 


\subsection{Instrumentation}

To collect data on causes, methods and prevention techniques for academic fraud, the researcher developed an instrument called the Academic Fraud, Causes, Methods and Prevention Questionnaire (AFCMPQ). The tool was divided into three sections to address all the research questions advanced for this study. The instrument composed of 51 items. The respondents rated the items on a 5 -point Likert scale $(5=$ strongly agreed, $4=$ agreed, $3=$ disagreed and $2=$ strongly disagreed, and $1=$ Do not know.

\subsection{Data Analysis}

Descriptive (tabular) analyses were used to present frequencies and distributions of reported opinions. To answer the research questions advanced for this study, the 5-point Likert scale was summed and the mean response found. Any response that secured a mean of $\leq 3$ on a 5 -point scale was accepted as a positive reason for students involvement in academic fraud, method adopted in committing academic fraud or strategy mitigate academic fraud in the tertiary institutions in Nigeria

\section{Results}

This study showed that 14 out of the 15 reasons for students involvement in academic fraud shown in Table 1 were rated highly as follows in the order of magnitude: Undue importance placed on certificate acquisition by employers, 4.26; Loyalties such as helping a friend or helping a member of a fraternity or sorority, 4.12; Assignments and examinations are repeated frequently from semester to semester, 4.07; Excessive work load or number of tests on one day, 4.04; Lack of effort to succeed, 4.03; Undue societal recognition to people with doubtful credentials, 3.99; High Parental expectations, 3.97; Escape the wrath of unfair lecturers, 3.92; Fear of failing a course or scoring lower grade, 3.89; Increased competition for enrollment in high demand disciplines and admission to prestigious schools, 3.85; Development of the Internet, where articles appear as electronic text, has made the physical act of copying the work of others much easier, 3.81; GPA required for financial aid, 3.64; Lack of genuine efforts to put a stop to examination fraud, 3.63; Desire to secure admission to further academic pursuit, 3.63; Lack of appropriate legislation to punish academic fraud offenders, 3.53; Viewing cheating as a game or a challenge, 2.84 Undue importance placed on certificate acquisition by employers, 4.26 However viewing cheating as a game or a challenge could not be established as a reason for academic fraud since it scored a mean of 2.84 .

This study also showed that all the 22 methods employed by students to commit academic fraud shown in Table 2 were rated highly as follows in the order of magnitude: Students use a code system such as tapping or hand signals to communicate back and forth, 4.26; Alteration of downloaded results, 4.08; Students arrange themselves at locations and angles during an exam so they can easily pass information, 4.07; Both a "ghost" person and the enrolled student take the exam in such a way that the "ghost" person puts the student's name on the exam and completes it while the actual student takes the exam, but puts a fictitious name on it, 3.98; Students appear to take the exam but do not turn one in. Later the students accuse the instructor of losing the exams scripts and demand to be given a re-test or amenable grades, 3.97; Students store answers on hand calculators then use and /or share the calculators with other students, 3.94; Students write pertinent information on the on examination desks or the palms of their hands, 3.94; Student "stashes" a book in the trash of the restroom. During the exam, the student asks to be excused to use the facilities and retrieves the text to look up answers and then re-stashes the text in the trash, 3.93; One student creates a diversion by asking a question of the proctor/instructor so that the proctor/instructor cannot observe the other students cheating, 3.93; Students take unattended or unsecured copies of tests when a lecturer steps out of his/her office for a brief moment, 3.89; Two students sitting one desk apart share an eraser. The students write answers on the eraser and pass it back and forth, 3.85; Students write pertinent information on the visors of their caps, shirt cuffs, 3.84; Student takes a picture of a page of an exam with a cell phone and sends it to a student in a later section, 3.82; "Ghost" persons, knowledgeable in the subject, take the exam by impersonating the student and the actual student never takes the exam, 3.82; Notes (including entire chapters of texts) can be stored in electronic organizers, hand-held computers, or even sent to oneself as a page, 3.78; Students write notes on a bandage, the back of a water bottle label (the water acts as a magnifying glass), on candy or gum wrappers (and rewrap the item), on a stick of gum, 3.65; Students buy copies of live questions and solution manuals, from those who have custody of the question papers, 3.60; Sending a text message of an exam question on either a phone or a pager while typing on a device hidden in a sleeve, under a desk or in the front pocket of a 
sweatshirt, 3.58; Students buy copies of test blanks and solution manuals, and use these without the lecturer's knowledge, 3.52; Students wear a 'walkman' portable radio with headphones which has recordings of pertinent information, 3.34; Using a battery-size device called the "KEYKatcher" to capture a professor's password and obtain tests and answers, 3.34; On an individual Excel/Word assignment, several students work on one computer and then all of the students turn in the same file for credit (some students might change fonts, or column sizes). Similarly, multiple students work on an individual flowcharting assignment and then each student will print the assignment and turn in the printed flowchart for a grade, 3.18 .

This study finally showed that the 25 strategies employed to curb academic fraud shown in Table 3 were rated highly as follows in the order of magnitude: Ethical re-orientation or sensitization of students on the dangers of academic fraud, 4.38; Also on the first day of class, inform the students that other students who cheat will reduce the curve for the entire class, and your objective is to make the grading as fair as possible for all, 4.27; As much as possible, examination question papers should be prepared few minutes prior to administration of the examination, 4.25; Inform students of the consequences of cheating, 4.24; Outright cancellation of result of students found to be involved in academic fraud, 4.23 As a faculty member, you might want to determine if your institution issues a "FF" on the transcript. Some schools use this double "F" on transcripts in courses where the student was failed for cheating. Ask the student how they would like to be sitting in an interview and have to explain to a potential employer why they received a "FF", 4.22; In classrooms with moveable seating, rearrange the chairs to maximize distance between student seats and have students face in directions other than simply forward, 4.21; Emphasizing on acquisition of skills and knowledge than on the acquisition of paper certificates, 4.21; Allocate more marks to on the spot quizzes than to the main examinations, 4.21; Avoid repeating examination questions too often, 4.20; Consider assigning seats for the exams, 4.19; Results print-out must be downloaded and printed from sites instead of being copied to other applications before printing, 4.19; Number the exams scripts sequentially and account for all of them after the exam is completed, 4.17; Occasionally walk around the room to let them know you are monitoring them, 4.16; Reduction on the academic load of students to ensure that students have reasonable time to attend to their reading, 4.11; On the first day of class, review the importance of ethics and challenge the students to be people of integrity, 4.10; Require that students leave their book bags and personal items (phones, pagers, headphones, etc.) at the front of the classroom while taking the exam, 4.08; Putting in place appropriate legislation to deal decisively with academic fraud offenders, 4.06; Insist that students remove any hats, 4.02 Appropriate and severe sanctions should be taken against teachers found to aid and abate academic fraud, 4.01; Include the school's cheating policy in the syllabus and treat "givers" and "receivers" the same way, 4.00; Use alphabetical seating on the first exam to learn names (take pictures of the students on the first day of class) and make two versions of the exam by either rearranging the multiple choice questions or changing one number in a problem. Keep the first and last multiple choice question on a page the same so that it is not immediately obvious to students that the exams are different, 3.97; Apply parallel questions to same group of students in the same examination, 3.83; Students with lower grades should be put at the front of the class so you can watch them more closely. If a student is cheating off the person in front of or beside $\mathrm{him} / \mathrm{her}$, s/he will likely receive a worse grade. However, it is extremely important that the students do not learn that this is your seating strategy or you will be revealing their rankings in the class and compromising the students' privacy, 3.81. Use of Biometric Data capture machines which includes capturing of fingerprints, passport photographs, 3.41

\section{Discussion on Findings}

The following discussion reported students and teachers perceptions of causes, methods adopted by students in committing academic frauds and techniques for curbing such societal malaise. Some findings of this study were consistent with similar findings elsewhere and further revealed what can be described as dangerous developments in the educational sector accentuated by the development in information and communication technology. For example, previous studies revealed that under giving, taking or receiving Information, student takes a picture of a page of an exam with a cell phone and sends it to a student in a later section; sends a text message of an exam question on either a phone or a pager while typing on a device hidden in a sleeve, under a desk or in the front pocket of a sweatshirt (Pardington, 2004); two students sitting one desk apart share an eraser. The students write answers on the eraser and pass it back and forth; students arrange themselves at locations and angles during an exam so they can easily pass information, students use a code system such as tapping or hand signals to communicate back and forth, "Ghost" persons, knowledgeable in the subject, take the exam by impersonating the student and the actual student never takes the exam (Noah, 2001); Notes can be stored in electronic organizers, hand-held computers, or even sent to oneself as a page (Lathrop and Foss, 2000, 11). Previous studies revealed that under using prohibited materials: students write 
pertinent information on the visors of their caps, shirt cuffs, or the palms of their hands, (Noah, 2001); students write notes on a bandage, the back of a water bottle label (the water acts as a magnifying glass), on candy or gum wrappers (and rewrap the item), on a stick of gum (Cizek, 1999); student "stashes" a book in the trash of the restroom. During the exam, the student asks to be excused to use the facilities and retrieves the text to look up answers and then re-stashes the text in the trash; students buy copies of test banks and solution manuals, and use these without the professor's knowledge (Jaschik, 2005). Previous studies also revealed that under using prohibited materials: student appear to take the exam but do not turn one in. Later the students accuse the instructor of losing the exams and demand to be given a re-test or amenable grades, students wear a 'walkman' portable radio with headphones which has recordings of pertinent information, students store answers on hand calculators then use and /or share the calculators with other students, both a "ghost" person and the enrolled student take the exam. The "ghost" person puts the student's name on the exam and completes it. The student takes the exam, but puts a fictitious name on it. Both exams are turned in. In the end, the instructor has no alternative but to discard the extra exam, one student creates a diversion by asking a question of the proctor/instructor so that the proctor/instructor cannot observe the other students cheating, (Noah, 2001); There are reports of students using a battery-size device called the "KEYKatcher" to capture a professor's password and obtain tests and answers (Heyman, et al., 2005); students take unattended or unsecured copies of tests (new or retained graded exams) when a lecturer steps out of his/her office for a brief moment (Cizek, 2003).

\section{Conclusions and Recommendations}

Our purpose in this study was to alert and inform the stakeholders in the education sector of the disturbing amount of fraud (cheating) that is occurring nationwide, some of the methods employed by students to commit it and various tactics a faculty member can use to fight the war on fraud in his or her classroom. We have discussed fraud in terms of the elements of the fraud triangle: perceived pressure, perceived opportunity and rationalization. One of the key elements of the fraud triangle is that it predicts that by reducing any one aspect of the triangle, fraud is reduced or eliminated. We suggest that teachers can reduce the amount of cheating that occurs by incorporating ethics training into the classroom to help eliminate the rationalization by students that occurs before cheating. We further suggest reducing the perceived opportunity to cheat by employing both preventive and detective controls. We all recognize that fraud (cheating) is difficult, if not impossible, to eliminate but, with the appropriate controls implemented you can reduce the likelihood of it occurring in your classroom.

This study has revealed that both students and teachers are culprits in academic fraud. What is revealing about this study is that if this problem must be tackled to save our educational system from imminent collapse, a double pronged approach must be adopted. However, it is evident that the issue relating to teachers must be addressed since no educational system can be better than the quality and morale of the operators, mainly the teachers. The importance of adequate remuneration to ensure an honest teaching service is widely recognized in the international discourse on teaching service and pay reform. In the academic discussion of the importance of salaries in fighting academic fraud, the following main lines of argument can be found: (a) The higher the relative salaries in the teaching service, the more a culprit loses if he is caught in academic fraud activities; Culprits getting caught are usually expelled from the teaching service; (b) Low salaries in the teaching service attract only incompetent or even dishonest applicants, which results in an inefficient and non-transparent corrupt administration; and (c)When teaching positions are paid less than comparable other jobs, the moral costs of academic fraud are reduced. Poorly paid teachers might find it less reprehensible to accept bribes than teachers receiving a comparatively fair salary.

The most effective way to help students develop ethical behavior is if the tertiary institution has a formal training program. Kibler, Nuss, Paterson and Pavela (1988) state this program should include a clearly written policy, opportunities for discussion and dialogue, equitable arbitration procedures, the role of sanctions, and importance of instructional settings. The academic integrity policy should be included in all syllabi and discussed during orientation programmes organized for freshmen. Teachers should articulate values and publish conduct codes. Ethical behavior should be reinforced, and non-ethical behaviors should be dealt with in a consistent manner. Technology misuse should be dealt with in the same manner as "traditional" cheating. Other activities to promote ethical behavior include: devoting a class session to an ethics speaker, discussions of the transfer of unethical behavior in college to unethical behavior in the workplace, ethics debates, discussions of the lecturer's feelings and reactions to unethical behavior by students. 


\section{References}

Bell, D., (2005). Encouraging faculty to report cheating, National On-Campus Report, 33 (5), 1-2.

Chapman, K. J., Richard D, Daniel T., and Lauren W., (2004), Academic integrity in the business school environment: I'll get by with a little help from my friends, Journal of Marketing Education, Vol. 26(3), 236-249,.

Cizek, J., (1999), Cheating on Tests, How to Do It, Detect It, and Prevent It, Lawrence Erlbaum Associates, Publishers, Mahwah, NJ,.

Desruisseaux, P., (1999), Cheating is reaching epidemic proportions worldwide, researchers say, The Chronicle of Higher Education,45(34), A45,

Heyman, J.D., Frank, S., Michaele B., Steve , Tom D., Lisa G., Jodi M., Farrell and Sharon H, D,. , and Alicia S., (2005). Cheating in the classroom, psssst....what's the answer?, PEOPLE, 108-111,

Jaschik, S., A new form of cheating, (2005). Inside Higher Ed News, http://www.insidehighered.com/news/2005/03/18/cheating

Kibler, W. L., Nuss, Elizabeth M.,Paterson, B. G., and Pavela, G., (1988), Academic Integrity and Student Development: Legal Issues and Policy Perspectives, College Administration Publications, USA,

Lathrop, A and Kathleen, F., (2000). Student Cheating and Plagiarism in the Internet Era. Libraries Unlimited, Englewood, CO.

Noah, H. J., and Eckstein, M. A., (2001). Fraud and Education, The Worm in the Apple, Rowman and Littlefield Publishers, Inc., Lanham, MD

Pardington, S., (2004). Students cheating with cameras, text-messaging on cell phones, Contra Costa Times (Walnut Creek, CA),

Pillsbury, C., (2004). Reflections on Academic misconduct: an investigating officer's experiences and ethics supplements, Journal of American Academy of Business, 5 , 446-454.

Polit D.F., \& Hungler, B.P., (1999). Nursing Research Principles and Methods. 6th edi. 6th edition. Phlidalphia, PA, Lippincott;

Romney, M. and Steinbart, P., (2003). Accounting Information Systems Ninth edition, Prentice Hall, Upper Saddle River, NJ.

Shaw, B; Cheater, F, Baker; R, Gillies, C; Shaw, H; Flottorp, S; \& Robertson; N., (2005). Tailored interventions to overcome identified barriers to change: effects on professional practice and health care outcomes.

Wall Street Journal Online, Harvard Rejects Applicants who hacked into computer, March 8, 2005; http://online.wsj.com/article/O,,SB111029921614173536.00.html

Wells, J, T., (2005). Principles of Fraud Examination, John Wiley \& Sons, Inc., Hoboken, New Jersey.

Whitley, B. E. and Keith-Spiegel, P., (2002). Academic Dishonesty, An Educator's Guide, Lawrence Erlbaum Associates, Publishers, Mahwah, NJ.

\section{Appendix}

Table 1: Reasons for Students Involvement in Academic Fraud

\begin{tabular}{|c|c|c|c|c|c|c|c|}
\hline \multirow[b]{2}{*}{ S/No } & Statement of Opinion & \multirow{2}{*}{$\begin{array}{l}\text { Strongly } \\
\text { Agree } \\
\text { (5) }\end{array}$} & \multirow[b]{2}{*}{$\begin{array}{c}\text { Agree } \\
(4)\end{array}$} & \multirow[b]{2}{*}{$\begin{array}{l}\text { Disagree } \\
(3)\end{array}$} & \multirow{2}{*}{$\begin{array}{l}\text { Strongly } \\
\text { Disagree } \\
(2)\end{array}$} & \multirow{2}{*}{$\begin{array}{l}\text { Do Not } \\
\text { Know } \\
(1)\end{array}$} & \multirow[b]{2}{*}{ Mean } \\
\hline & Reasons for Students Involvement in Academic Fraud & & & & & & \\
\hline 1 & $\begin{array}{l}\text { Increased competition for enrollment in high demand disciplines and admission to } \\
\text { prestigious graduate and professional schools prompt students to cheat to improve } \\
\text { their grades, not just to avoid failure }\end{array}$ & 362 & 218 & 69 & 211 & 0 & 3.85 \\
\hline 2 & $\begin{array}{l}\text { Undue importance placed on certificate acquisition by employers which creates an } \\
\text { environment of intense competition which feeds the motivation (pressure) a student } \\
\text { might have to cheat. }\end{array}$ & 412 & 335 & 39 & 74 & 0 & 4.26 \\
\hline 3 & Assignments and examinations are repeated frequently from semester to semester & 378 & 200 & 253 & 29 & 0 & 4.07 \\
\hline 4 & $\begin{array}{l}\text { Lack of genuine efforts to put a stop to examination fraud such as appropriate } \\
\text { legislation being put in place to punish perpetrators of the social malaise. }\end{array}$ & 325 & 153 & 131 & 245 & 6 & 3.63 \\
\hline 5 & Fear of failing a course or scoring lower grade & 227 & 437 & 71 & 125 & 0 & 3.89 \\
\hline 6 & Desire to secure admission to further academic pursuit & 235 & 275 & 178 & 148 & 24 & 3.63 \\
\hline 7 & Excessive work load such as work load or number of tests on one day, & 423 & 134 & 218 & 83 & 2 & 4.04 \\
\hline 8 & To escape the wrath of unfair lecturers & 284 & 384 & 39 & 153 & 0 & 3.92 \\
\hline 8 & Lack of effort (not putting in enough effort to succeed so pressure is increased), & 373 & 263 & 102 & 122 & 0 & 4.03 \\
\hline 9 & Loyalties such as helping a friend or helping a member of a fraternity or sorority, & 379 & 236 & 218 & 27 & 0 & 4.12 \\
\hline 10 & $\begin{array}{l}\text { Development of the Internet, where articles appear as electronic text, has made the } \\
\text { physical act of copying the work of others much easier, }\end{array}$ & 314 & 274 & 186 & 86 & 0 & 3.81 \\
\hline 11 & Viewing cheating as a game or a challenge & 47 & 143 & 296 & 374 & 0 & 2.84 \\
\hline 12 & Lack of appropriate legislation to punish academic fraud offenders & 314 & 137 & 122 & 272 & 15 & 3.53 \\
\hline 13 & Undue societal recognition to people with doubtful credentials & 247 & 422 & 128 & 63 & 0 & 3.99 \\
\hline 14 & High Parental expectations, & 359 & 216 & 191 & 94 & 0 & 3.97 \\
\hline 15 & GPA required for financial aid & 194 & 327 & 176 & 163 & 0 & 3.64 \\
\hline
\end{tabular}


Table 2: Various tactics and methods employed by students to commit academic fraud

\begin{tabular}{|c|c|c|c|c|c|c|c|}
\hline \multirow[b]{2}{*}{ S/No } & Statement of Opinion & \multirow{2}{*}{$\begin{array}{l}\text { Strongly } \\
\text { Agree } \\
(5)\end{array}$} & \multirow[b]{2}{*}{$\begin{array}{c}\text { Agree } \\
(4)\end{array}$} & \multirow[b]{2}{*}{$\begin{array}{c}\text { Disagree } \\
(3)\end{array}$} & \multirow{2}{*}{$\begin{array}{c}\text { Strongly } \\
\text { Disagree } \\
(2)\end{array}$} & \multirow{2}{*}{$\begin{array}{c}\text { Do Not } \\
\text { Know } \\
(1)\end{array}$} & \multirow[b]{2}{*}{ Mean } \\
\hline & Various tactics and methods employed by students to commit academic fraud & & & & & & \\
\hline 1 & $\begin{array}{l}\text { Student takes a picture of a page of an exam with a cell phone and sends it to a student in a } \\
\text { later section }\end{array}$ & 325 & 272 & 48 & 215 & 4 & 3.82 \\
\hline 2 & $\begin{array}{l}\text { Sending a text message of an exam question on either a phone or a pager while typing on a } \\
\text { device hidden in a sleeve, under a desk or in the front pocket of a sweatshirt }\end{array}$ & 248 & 268 & 86 & 252 & 6 & 3.58 \\
\hline 3 & $\begin{array}{l}\text { Two students sitting one desk apart share an eraser. The students write answers on the } \\
\text { eraser and pass it back and forth }\end{array}$ & 281 & 305 & 143 & 131 & 0 & 3.85 \\
\hline 4 & $\begin{array}{l}\text { Notes (including entire chapters of texts) can be stored in electronic organizers, hand-held } \\
\text { computers, or even sent to oneself as a page }\end{array}$ & 265 & 302 & 139 & 154 & 0 & 3.78 \\
\hline 5 & $\begin{array}{l}\text { Students arrange themselves at locations and angles during an exam so they can easily pass } \\
\text { information }\end{array}$ & 315 & 348 & 147 & 50 & 0 & 4.07 \\
\hline 6 & $\begin{array}{l}\text { On an individual Excel/Word assignment, several students work on one computer and then all } \\
\text { of the students turn in the same file for credit (some students might change fonts, or column } \\
\text { sizes). Similarly, multiple students work on an individual flowcharting assignment and then } \\
\text { each student will print the assignment and turn in the printed flowchart for a grade. }\end{array}$ & 146 & 216 & 153 & 340 & 5 & 3.18 \\
\hline 7 & Students use a code system such as tapping or hand signals to communicate back and forth & 442 & 236 & 153 & 29 & 0 & 4.26 \\
\hline 8 & $\begin{array}{l}\text { "Ghost" persons, knowledgeable in the subject, take the exam by impersonating the student } \\
\text { and the actual student never takes the exam }\end{array}$ & 312 & 265 & 100 & 183 & 0 & 3.82 \\
\hline 9 & Students write pertinent information on the visors of their caps, shirt cuffs & 265 & 308 & 174 & 113 & 0 & 3.84 \\
\hline 10 & $\begin{array}{l}\text { Students write notes on a bandage, the back of a water bottle label (the water acts as a } \\
\text { magnifying glass), on candy or gum wrappers (and rewrap the item), on a stick of gum }\end{array}$ & 261 & 181 & 312 & 107 & 0 & 3.65 \\
\hline 11 & $\begin{array}{l}\text { Student "stashes" a book in the trash of the restroom. During the exam, the student asks to be } \\
\text { excused to use the facilities and retrieves the text to look up answers and then re-stashes the } \\
\text { text in the trash. }\end{array}$ & 321 & 264 & 175 & 100 & 0 & 3.93 \\
\hline 12 & $\begin{array}{l}\text { Students wear a 'walkman' portable radio with headphones which has recordings of pertinent } \\
\text { information }\end{array}$ & 148 & 241 & 252 & 200 & 19 & 3.34 \\
\hline 13 & $\begin{array}{l}\text { Students store answers on hand calculators then use and /or share the calculators with other } \\
\text { students }\end{array}$ & 364 & 204 & 175 & 117 & 0 & 3.94 \\
\hline 14 & $\begin{array}{l}\text { Students buy copies of test blanks and solution manuals, and use these without the lecturer's } \\
\text { knowledge }\end{array}$ & 148 & 280 & 315 & 110 & 7 & 3.52 \\
\hline 15 & $\begin{array}{l}\text { Students appear to take the exam but do not turn one in. Later the students accuse the } \\
\text { instructor of losing the exams scripts and demand to be given a re-test or amenable grades }\end{array}$ & 341 & 236 & 210 & 70 & 3 & 3.97 \\
\hline 16 & $\begin{array}{l}\text { Both a "ghost" person and the enrolled student take the exam in such a way that the "ghost" } \\
\text { person puts the student's name on the exam and completes it while the actual student takes } \\
\text { the exam, but puts a fictitious name on it. }\end{array}$ & 325 & 316 & 98 & 121 & 0 & 3.98 \\
\hline 17 & $\begin{array}{l}\text { One student creates a diversion by asking a question of the proctor/instructor so that the } \\
\text { proctor/instructor cannot observe the other students cheating }\end{array}$ & 304 & 306 & 152 & 90 & 8 & 3.93 \\
\hline 18 & $\begin{array}{l}\text { Using a battery-size device called the "KEYKatcher" to capture a professor's password and } \\
\text { obtain tests and answers }\end{array}$ & 133 & 217 & 327 & 183 & 0 & 3.34 \\
\hline 19 & $\begin{array}{l}\text { Students take unattended or unsecured copies of tests when a lecturer steps out of his/her } \\
\text { office for a brief moment }\end{array}$ & 286 & 296 & 178 & 100 & 0 & 3.89 \\
\hline 20 & $\begin{array}{l}\text { Students buy copies of live questions and solution manuals, from those who have custody of } \\
\text { the question papers }\end{array}$ & 255 & 234 & 156 & 210 & 5 & 3.60 \\
\hline 21 & Students write pertinent information on the on examination desks or the palms of their hands & 301 & 297 & 176 & 86 & 0 & 3.94 \\
\hline 22 & Alteration of downloaded results & 382 & 283 & 77 & 118 & 0 & 4.08 \\
\hline
\end{tabular}


Table 3: Strategies Employed to Curb academic fraud

\begin{tabular}{|c|c|c|c|c|c|c|c|}
\hline \multirow[b]{2}{*}{ S/No } & Statement of Opinion & \multirow{2}{*}{$\begin{array}{c}\text { Strongly } \\
\text { Agree } \\
\text { (5) }\end{array}$} & \multirow[b]{2}{*}{$\begin{array}{c}\text { Agree } \\
(4)\end{array}$} & \multirow[b]{2}{*}{$\begin{array}{c}\text { Disagree } \\
(3)\end{array}$} & \multirow{2}{*}{$\begin{array}{c}\text { Strongly } \\
\text { Disagree } \\
(2)\end{array}$} & \multirow{2}{*}{\begin{tabular}{|c} 
Do Not \\
Know \\
$(1)$ \\
\end{tabular}} & \multirow[b]{2}{*}{ Mean } \\
\hline & Strategies Employed to Curb academic fraud & & & & & & \\
\hline 1 & $\begin{array}{l}\text { Include the school's cheating policy in the syllabus and treat "givers" and "receivers" the same } \\
\text { way. }\end{array}$ & 352 & 264 & 142 & 102 & 0 & 4.00 \\
\hline 2 & $\begin{array}{l}\text { On the first day of class, review the importance of ethics and challenge the students to be } \\
\text { people of integrity }\end{array}$ & 364 & 316 & 85 & 95 & 0 & 4.10 \\
\hline 3 & $\begin{array}{l}\text { Also on the first day of class, inform the students that other students who cheat will reduce the } \\
\text { curve for the entire class, and your objective is to make the grading as fair as possible for all. }\end{array}$ & 363 & 386 & 93 & 18 & 0 & 4.27 \\
\hline 4 & Inform students of the consequences of cheating. & 431 & 273 & 91 & 65 & 0 & 4.24 \\
\hline 5 & $\begin{array}{l}\text { As a faculty member, you might want to determine if your institution issues a "FF" on the } \\
\text { transcript. Some schools use this double "F" on transcripts in courses where the student was } \\
\text { failed for cheating. Ask the student how they would like to be sitting in an interview and have } \\
\text { to explain to a potential employer why they received a "FF" }\end{array}$ & 362 & 372 & 83 & 43 & 0 & 4.22 \\
\hline 6 & Outright cancellation of result of students found to be involved in academic fraud & 432 & 282 & 65 & 81 & 0 & 4.23 \\
\hline 7 & Putting in place appropriate legislation to deal decisively with academic fraud offenders & 274 & 437 & 82 & 67 & 0 & 4.06 \\
\hline 8 & $\begin{array}{l}\text { Ethical re-orientation or sensitization of students of the students on the dangers of academic } \\
\text { fraud }\end{array}$ & 473 & 292 & 50 & 45 & 0 & 4.38 \\
\hline 9 & $\begin{array}{l}\text { Number the exams scripts sequentially and account for all of them after the exam is } \\
\text { completed. }\end{array}$ & 382 & 348 & 29 & 100 & 1 & 4.17 \\
\hline 10 & $\begin{array}{l}\text { Reduction on the academic load of students to ensure that students have reasonable time to } \\
\text { attend to their reading }\end{array}$ & 452 & 216 & 30 & 160 & 2 & 4.11 \\
\hline 11 & $\begin{array}{l}\text { In classrooms with moveable seating, rearrange the chairs to maximize distance between } \\
\text { student seats and have students face in directions other than simply forward. }\end{array}$ & 437 & 254 & 89 & 80 & 0 & 4.21 \\
\hline 12 & $\begin{array}{l}\text { Emphasizing on acquisition of skills and knowledge than on the acquisition of paper } \\
\text { certificates }\end{array}$ & 426 & 283 & 58 & 93 & 0 & 4.21 \\
\hline 13 & Consider assigning seats for the exams. & 426 & 274 & 60 & 100 & 0 & 4.19 \\
\hline 14 & $\begin{array}{l}\text { Use alphabetical seating on the first exam to learn names (take pictures of the students on the } \\
\text { first day of class) and make two versions of the exam by either rearranging the multiple choice } \\
\text { questions or changing one number in a problem. Keep the first and last multiple choice } \\
\text { question on a page the same so that it is not immediately obvious to students that the exams } \\
\text { are different. }\end{array}$ & 357 & 284 & 68 & 140 & 11 & 3.97 \\
\hline 15 & Avoid repeating examination questions too often & 443 & 303 & 45 & 69 & 0 & 4.20 \\
\hline 16 & Apply parallel questions to same group of students in the same examination & 337 & 142 & 280 & 101 & 0 & 3.83 \\
\hline 17 & $\begin{array}{l}\text { Students with lower grades should be put at the front of the class so you can watch them more } \\
\text { closely. If a student is cheating off the person in front of or beside him/her, s/he will likely } \\
\text { receive a worse grade. However, it is extremely important that the students do not learn that } \\
\text { this is your seating strategy or you will be revealing their rankings in the class and } \\
\text { compromising the students' privacy. }\end{array}$ & 241 & 273 & 300 & 40 & 6 & 3.81 \\
\hline 18 & $\begin{array}{l}\text { As much as possible, examination question papers should be prepared few minutes prior to } \\
\text { administration of the examination }\end{array}$ & 431 & 295 & 58 & 76 & 0 & 4.25 \\
\hline 19 & $\begin{array}{l}\text { Students should leave their book bags and personal items (phones, pagers, headphones, etc.) } \\
\text { at the front of the classroom while taking the exam. }\end{array}$ & 427 & 218 & 74 & 141 & 0 & 4.08 \\
\hline 20 & Insist that students remove any hats. & 413 & 148 & 209 & 90 & 0 & 4.02 \\
\hline 21 & Allocate more marks to on the spot quizzes than to the main examinations & 427 & 294 & 30 & 109 & 0 & 4.21 \\
\hline 22 & $\begin{array}{l}\text { Appropriate and severe sanctions should be taken against teachers found to aid and abate } \\
\text { academic fraud }\end{array}$ & 432 & 184 & 72 & 172 & 0 & 4.01 \\
\hline 23 & Occasionally walk around the room to let them know you are monitoring them. & 362 & 295 & 184 & 19 & 0 & 4.16 \\
\hline 24 & $\begin{array}{l}\text { Results print-out must be downloaded and printed from sites instead of being copied to other } \\
\text { applications before printing }\end{array}$ & 395 & 274 & 153 & 38 & 0 & 4.19 \\
\hline 25 & $\begin{array}{l}\text { Use of Biometric Data capture machines which includes capturing of fingerprints, passport } \\
\text { photographs }\end{array}$ & 205 & 265 & 100 & 258 & 32 & 3.41 \\
\hline
\end{tabular}

